http:/ / dx.doi.org/10.5597/lajam00158

\title{
ECOLOGY AND CONSERVATION STATUS OF TUCUXI (SOTALIA FLUVIATILIS) in the Pacaya-Samiria Reserve, Peru
}

\author{
TAMARA L. McGuire ${ }^{1,2 *}$
}

\begin{abstract}
Aвstract: The distribution, relative abundance, group size, reproductive seasonality, and conservation status of tucuxi (Sotalia fluviatilis) were investigated in Peru's Pacaya-Samiria National Reserve from 1996 to 2000. Data collection consisted of boat-based surveys of dolphins and habitat, necropsies, photo-identification of individual dolphins, and interviews with local people. Mean encounter rates were between $0.01-0.80$ tucuxi $/ \mathrm{km}$ in rivers, and $0.05-2.17$ tucuxi $/ \mathrm{km}^{2}$ in lakes, and were within the ranges reported for riverine tucuxi throughout their distribution. Encounter rates were highest in confluences, intermediate in lakes, and lowest in rivers. Encounter rates increased with river width. Most tucuxis were seen within $100 \mathrm{~m}$ from shore in large rivers, and large groups were associated with confluence areas and mid-channel islands. Within lakes, tucuxis were associated with areas of deeper water. Tucuxis were not found in waters $<3 \mathrm{~m}$ depth in rivers, or $<1.8 \mathrm{~m}$ depth in lakes. Seasonal differences in encounter rates did not exist in lakes and rivers. In confluences tucuxis occurred in highest densities during low water, and lowest densities during high water. Diurnal patterns of occurrence were not observed. Tucuxis were seen most often as singles or pairs, although groups as large as 13 were observed. Significant seasonal differences in group size were not detected. Neonate tucuxi were observed in all seasons, with a slight peak in encounter rates during high water. Abundance estimates were affected by survey methods, and strengths and weaknesses of various methods are discussed. Photo-identification rates were low, and this method did not yield information about tucuxi site fidelity, movement patterns, social structure, or population size. Local people in the Reserve did not seem to have the same myths and general apprehension about tucuxis as for the other sympatric dolphin, Inia. There was no evidence that tucuxi were poisoned by fishermen, unlike Inia. Potential threats to tucuxi in this region were entanglement in fishing gear, mercury in migratory fish from gold mining elsewhere, oil spills, ship strikes, and disturbance from boats. Only one dead tucuxi was encountered, and had been entangled in a turtle net. Tucuxi teeth were found for sale in local markets.
\end{abstract}

REsumEN: Desde 1996 al año 2000 se estudió la distribución, abundancia relativa, tamaño de grupo, estacionalidad reproductiva y el estatus del delfín de rió tucuxi (Sotalia fluviatilis) en la Reserva Nacional Pacaya-Samiria del Perú. La toma de datos consistió en evaluaciones de delfines y hábitat desde botes, necropsias, foto-identificación de individuos, y entrevistas con gente local. Las tasas medias de encuentro se encuentran entre 0.01-0.80 tucuxi $/ \mathrm{km}$ en ríos, y de $0.05-2.17$ tucuxi $/ \mathrm{km}^{2}$ en lagos, y estuvieron dentro de los rangos reportados para tucuxi a lo largo de su distribución. Las tasas de encuentro fueron más altas en confluencias, intermedias en lagos y las más bajas en ríos. Las tasas de encuentro incrementaron con el ancho del rió. La mayoría de los delfines fueron vistos a 100m de la orilla de ríos principales, y grupos numerosos fueron asociados con confluencias y canales al medio de islas. En los lagos, tucuxis estuvieron asociados con áreas de aguas mas profundas. En ríos, tucuxis no fueron encontrados en aguas $<3 \mathrm{~m}$ de profundidad, $\mathrm{o}<1.8 \mathrm{~m}$ profundidad en lagos. No se encontraron diferencias estacionales en las tasas de encuentros en lagos y ríos. Tucuxis se encontraron en mayores densidades en confluencias durante aguas bajas y en bajas densidades durante aguas altas. No se observaron patrones de ocurrencia diurna. Se observaron más a menudo tucuxis solitarios o en pares, aunque se observaron grupos de hasta 13. No se detectaron diferencias estacionales significativas. En todas las estaciones se observaron neonatos de tucuxi con un ligero pico durante aguas altas. Las estimaciones de abundancia fueron afectadas por los métodos de muestreo, y se discute la fortaleza y debilidad de varios métodos. Las tasas de delfines foto-identificados fueron bajas y no permiten información relacionada con fidelidad de lugar, patrones de movimiento, estructura social, o tamaño poblacional. La gente local de la reserva no tiene los mismos mitos y aprensiones generales sobre los tucuxis como para el simpátrico delfín, Inia. No se encontró evidencia que los pescadores envenenaran a Sotalia como con Inia. Las potenciales amenazas al tucuxi en esta región fueron el emmallamiento en redes de pesca, mercurio presente en peces migratorios vertidos por minas de otras regiones, derrames de petróleo, tráfico y colisiones con embarcaciones. Solamente se encontró un tucuxi muerto que había sido enredado en una red para tortugas. Se encontraron dientes de tucuxi en mercados locales.

KEYwORDs: Sotalia fluviatilis, tucuxi, river dolphin, Pacaya-Samiria Reserve, Peruvian Amazon, abundance estimates, seasonality.

\section{Introduction}

The conservation status of the tucuxi (Sotalia fluviatilis) is designated as 'data deficient' by the IUCN Red List'. Population estimates of tucuxi are scarce, in part because of the vast range of the species (the Amazon Basin and the lower Orinoco River Basin), and in part because of challenging logistics and survey methods. Most studies have reported results in terms of relative dolphin densities or encounter rates (Layne, 1958; Magnusson et al., 1980; Best and da Silva, 1989; Borobia et al., 1991; da Silva, 1994; da Silva and Best, 1996; Herman et al.,1996; Leatherwood, 1996; Trujillo, 1992; Vidal et al., 1997; Galindo, 1998; Henningsen, 1998; Reeves et al.,1999; McGuire, 2002; Martin et al., 2004), as true densities are often difficult to obtain due to the complex

\footnotetext{
${ }^{1}$ Marine Mammal Research Program, Texas A\&M University, Galveston, TX 77551-5923, USA

${ }^{2}$ Current address: LGL Alaska Research Associates, 2000 West International Airport Road, Suite C1 Anchorage, AK 99502, USA

* Corresponding author, e-mail: tmcguire@lgl.com

${ }^{3}$ IUCN (2010) IUCN Red List of Threatened Species. Version 2010.4. Available online at <http:/ / www.iucnredlist.org >. Consulted on 26 April 2011.
} 
habitat, elusive behavior, and patchy distribution of tucuxi. Several related studies of river dolphin (Sotalia and Inia) ecology and conservation have been conducted in Peru's Pacaya-Samiria Reserve as part of a long-term project initiated in 1991 (Leatherwood, 1996; Leatherwood et al., 2000), and continued by Henningsen (1998), Zúñiga (1999), and McGuire (2002). The Pacaya-Samiria Reserve was selected because it offered a relatively pristine environment in which to obtain baseline data. In this paper, I summarize unpublished and published results of an investigation of the distribution, relative abundance, group size, reproductive seasonality and conservation status of tucuxi in Peru's Pacaya-Samiria National Reserve. More detailed presentation of methods, results, and discussion can be found in McGuire (2002), McGuire and Aliaga-Rossel (2007), and McGuire and Henningsen (2007).

\section{Material and Methods}

The Pacaya-Samiria Reserve is located in the far western Amazon Basin (Figure 1), and at 2080000ha, it is the largest reserve in Peru, with over $10000 \mathrm{~km}$ of linear waterways. Four seasons, each approximately three months long, are determined by water levels: high water, falling water, low water, and rising water. Twenty-eight research cruises were conducted between 1996-2000 (312d), and all seasons and aquatic habitat types were surveyed (Figure 1, Table 1).

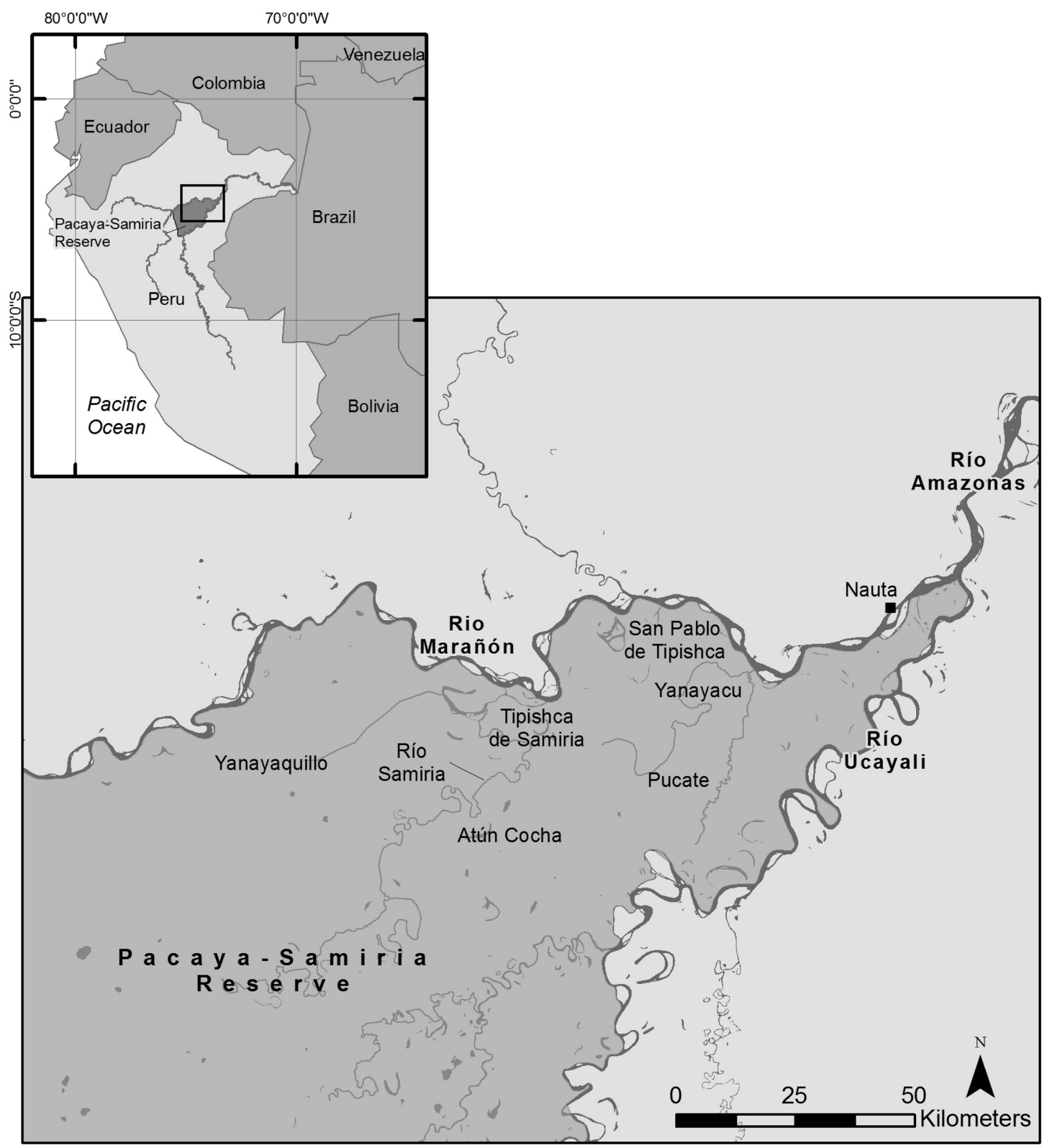

Figure 1. Map of the study area in the Pacaya-Samiria National Reserve, Peru. 
Table 1. Rivers surveyed for tucuxis in the Pacaya-Samiria Reserve, Peru.

\begin{tabular}{lccl}
\hline \hline \multicolumn{1}{c}{ LOCATION } & $\begin{array}{c}\text { MEAN WIDTH }(\mathrm{m}) \\
\text { DURING HIGH WATER }\end{array}$ & $\begin{array}{c}\text { LENGTH OR AREA } \\
\text { SURVEYED }\end{array}$ & WATER TYPE $^{1}$ \\
\hline \hline Marañón River & 910 & $82.0 \mathrm{~km}$ & white \\
Samiria River, section 1* & 300 & $16.0 \mathrm{~km}$ & mixed white and black \\
Samiria River, section 2* & 152 & $163.0 \mathrm{~km}$ & black \\
Yanayaquillo River & 49 & $5.5 \mathrm{~km}$ & black \\
Atun Caño & 50 & $5.0 \mathrm{~km}$ & black \\
Yanayacu River & 99 & $10.7 \mathrm{~km}$ & black, mixed in lower reach \\
Pucate River & 104 & $5.8 \mathrm{~km}^{*}$ & black \\
Lake San Pablode Tipishca & 450 & $15.0 \mathrm{~km}^{2}$ & mixed \\
Lake Atun Cocha & 645 & $6.0 \mathrm{~km}^{2}$ & black \\
Lake Tipishca del Samiria & 878 & $14.6 \mathrm{~km}^{2}$ & black \\
\hline \hline
\end{tabular}

*Because of differences in water type, width, boat traffic, and bank vegetation, the Samiria River was divided into two sections for surveys: section 1 was the $16 \mathrm{~km}$ reach from the mouth to the ranger station controlling access to the Reserve, and section 2 was upriver.

${ }^{1}$ Black waters are relatively transparent and high in tannic acids derived from local forest vegetation, while white waters are rich in nutrients and sediments from Andean runoff.

Data collection consisted of boat-based surveys of dolphins and habitat, photographs and necropsies of dolphins, and interviews with local people. Surveys were conducted from a $20 \mathrm{~m}$ long riverboat with $1 \mathrm{~m}$ draw and an observer eye height of 7m (1996-1999) and an $18 \mathrm{~m}$ long riverboat with a $0.9 \mathrm{~m}$ draw and an observer eye height of $3.5 \mathrm{~m}$ (2000), traveling at a mean speed of $9 \mathrm{~km} / \mathrm{h}$. Two experienced observers and two to four assistants scanned a total arc of $225^{\circ}$ extending from mid-bow towards stern on each side. Time of day, location (using GPS), distance to nearest shore, number and species of dolphins, and presence of neonates were recorded for each sighting. Tucuxi were differentiated from sympatric 'bufeo' or 'boto' (Inia) on the basis of dorsal fins, body size and shape, and surfacing behavior. Groups were defined as dolphins of the same species within five body lengths of each other. Every 10min, the survey vessel position, wind speed, boat speed, river depth, and river width were recorded. Most waterways were surveyed with direct counts and $100 \%$ strip-width transects. The Marañón River was surveyed with a modified strip transect because of navigational hazards and strong currents; here the survey vessel traveled within 50$100 \mathrm{~m}$ of the erosional shore, and traversed the river when this shore changed sides as the river turned, resulting in a strip transect of $50-100 \mathrm{~m}$ on one side, and indefinite width on the other. Smaller tributaries were sampled from skiffs powered by outboard motors. Behavioral observations and photographs for photo-identification were collected opportunistically during transects of lakes and rivers, and were made primarily during days spent scanning confluences areas from stationary vessels, sunup to sundown, for a total of $461 \mathrm{hr}$.
Data were stratified according to season, time of day, habitat and location. Single-factor ANOVAs were used to compare means among similar strata, such as encounter rates according to season. Data were first examined for normality. When necessary, data were transformed with the function $\ln (x+1)$ in order to correct for unequal variance. If the transformation failed to improve normality, the Kruskal-Wallis test was used to compare sample medians. Results of statistical tests were considered significant at the $P E$ 0.05 level. Standard deviations (SD) about the mean are in parenthesis following the mean. Coefficients of Variance $(\mathrm{CV})$, defined as the standard deviation of a sample divided by the mean of the sample, are reported as a measure of the relative variability of estimates.

\section{Results}

Tucuxi encounter rates were highest in confluences, intermediate in lakes, and lowest in rivers (Tables 2 and 3). Encounter rates generally increased with river width, and with lake size. In the Marañón River, 53\% of tucuxis were seen $<100 \mathrm{~m}$ from shore, $24.5 \% 100$ $200 \mathrm{~m}$, and $22.5 \%>200 \mathrm{~m}$, and $68 \%$ of large groups (> five tucuxis) were seen in confluences or around midchannel islands. In the Samiria River, 35\% of large groups were seen in confluences, and $41 \%$ were seen in river bends $<90 \%$. Tucuxis occurred throughout all of the surveyed lakes, but were encountered in highest concentrations in the deepest areas of the lakes. Tucuxi occurred in lakes as shallow as $1.8 \mathrm{~m}$ mean depth and in rivers as shallow as $3.0 \mathrm{~m}$ mean depth (Table 4). Encounter rates did not differ significantly according to season (Tables 2 and 3 ) in 
any of the surveyed lakes or rivers (except when tucuxi were absent during extreme low water in the shallowest waterways), and variation in dolphin abundance was greater within-seasons than amongseasons. In confluences, tucuxi densities were inversely related to seasonal water levels. There was no association between tucuxi occurrence and time of day in any habitat $(\mathrm{P}=0.14$; sampling restricted to 0600-1800hr). Tucuxi were most often seen as singles or pairs: $37 \%$ of all sightings were of single dolphins, $38 \%$ were of pairs, $14 \%$ of triples, and $10 \%$ were of groups of greater than three and up to 13 individuals. Seasonal differences in mean group size were not statistically significant in most locations, and mean group size was always between one and three (Table $5)$. Neonates were observed in all seasons, with a slight peak during high water. Mating behavior was only observed once during falling water and once during rising water. Photo-identification was unsuccessful; tucuxis were difficult to identify because they avoided boats, did not remain long in any one area, surfaced quickly and unpredictably and generally lacked visible, distinctive marks (McGuire and Henningsen, 2007). Different researchers working in the Pacaya-Samiria Reserve over a 10yr period have used different survey methods and have obtained different dolphin encounter rates for the same locations (Table 6). Direct counts of dolphins made in the same lake on the same or consecutive days also differed between different survey methods (using different routes, vessels, and number of observers; Table 7). One dead tucuxi was encountered between 1996-2000: an adult female, $176 \mathrm{~cm}$ total length (straight length, snout to tail notch), found dead and entangled in a net used for illegal capture of aquatic turtles.

Table 2. Seasonal tucuxi abundance in lakes and confluences of the Pacaya-Samiria Reserve.

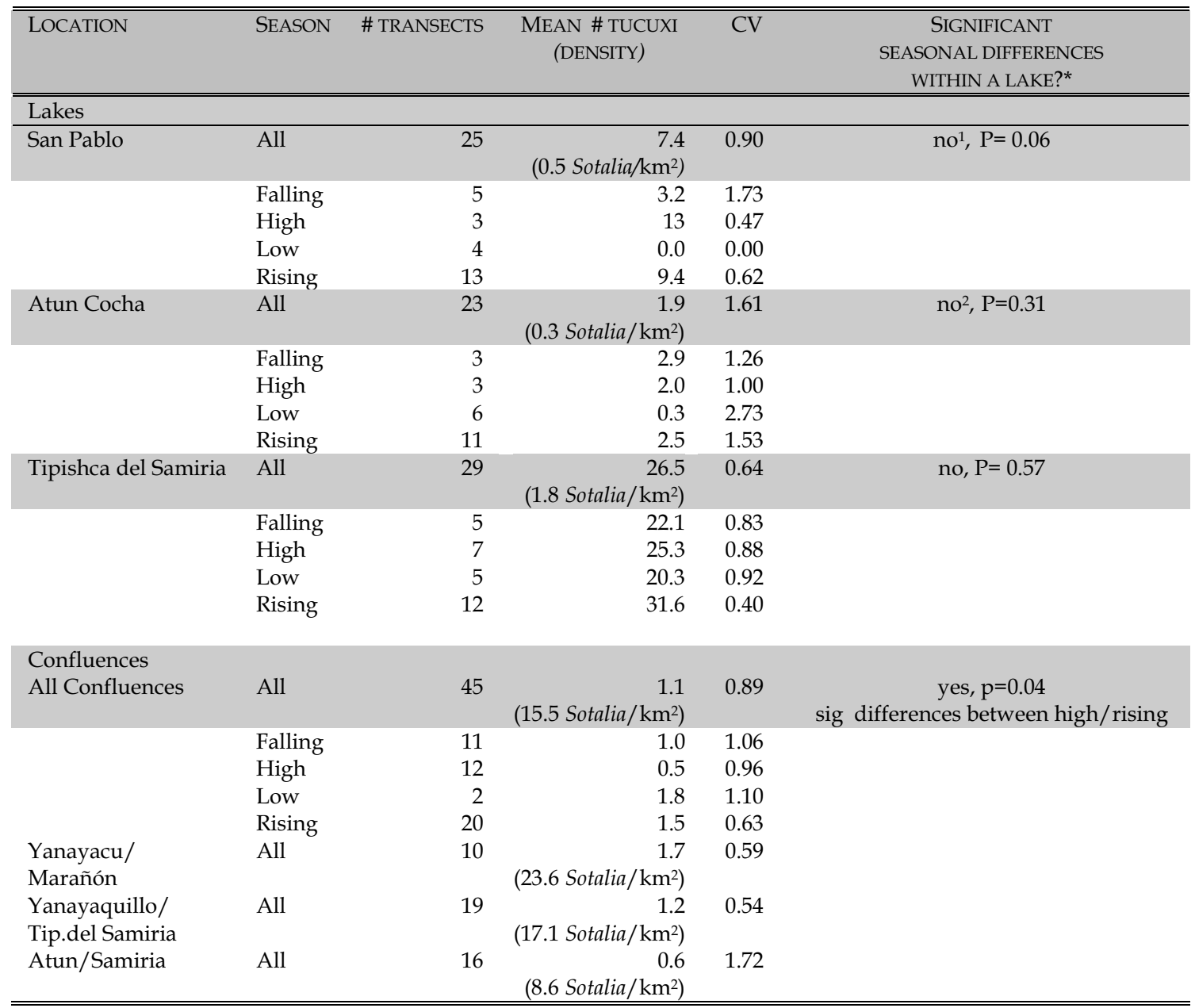

* Single factor ANOVAs were used to compare means among seasons. When data were not normally distributed, the Kruskal-Wallis test was used to compare sample medians.

${ }^{1}$ Sotalia not seen in this lake during low water; statistical comparisons were made among the means from all other seasons.

${ }^{2}$ Lake became completely dry during the end of the low-water season; this period was excluded from the analyses. 
Table 3. Tucuxi encounter rates in rivers of the Pacaya-Samiria Reserve.

\begin{tabular}{|c|c|c|c|c|c|}
\hline RIVER & SEASON & $\begin{array}{c} \\
\text { SURVEYS }\end{array}$ & $\begin{array}{c}\text { MEAN \# TUCUXI } \\
/ \mathrm{km}\end{array}$ & $\mathrm{CV}$ & $\begin{array}{c}\text { SIGNIFICANT } \\
\text { SEASONAL } \\
\text { DIFFERENCES } \\
\text { WITHIN A RIVER*? }\end{array}$ \\
\hline \multirow[t]{5}{*}{ Marañón } & All & 39 & 0.4 & 0.65 & no, $P=0.46$ \\
\hline & Falling & 9 & 0.4 & 0.72 & \\
\hline & High & 7 & 0.5 & 0.58 & \\
\hline & Low & 4 & 0.5 & 0.80 & \\
\hline & Rising & 19 & 0.3 & 0.63 & \\
\hline \multirow[t]{5}{*}{ Samiria (1) } & All & 11 & 0.3 & 1.27 & no, $P=0.15$ \\
\hline & Falling & 4 & 0.1 & 1.80 & \\
\hline & High & 3 & 0.7 & 0.68 & \\
\hline & Low & 3 & 0.2 & 0.80 & \\
\hline & Rising & 1 & 0.8 & 0.00 & \\
\hline \multirow{5}{*}{ Samiria (2) } & All & 32 & 0.4 & 0.50 & no, $\mathrm{P}=0.17$ \\
\hline & Falling & 9 & 0.5 & 0.48 & \\
\hline & High & 7 & 0.2 & 0.70 & \\
\hline & Low & 5 & 0.4 & 0.67 & \\
\hline & Rising & 11 & 0.3 & 0.57 & \\
\hline \multirow[t]{5}{*}{ Yanayaquillo } & All & 50 & 0.1 & 5.60 & no, $\mathrm{P}=0.44^{1}$ \\
\hline & Falling & 10 & 0.01 & 5.00 & \\
\hline & High & 14 & 0.01 & 5.00 & \\
\hline & Low & 6 & 0.0 & 0.00 & \\
\hline & Rising & 20 & 0.3 & 2.90 & \\
\hline \multirow[t]{5}{*}{ Atun Caño } & All & 52 & 0.2 & 1.20 & no, $\mathrm{P}=0.17$ \\
\hline & Falling & 8 & 0.3 & 1.10 & \\
\hline & High & 14 & 0.1 & 1.30 & \\
\hline & Low & 10 & 0.1 & 1.40 & \\
\hline & Rising & 20 & 0.2 & 1.40 & \\
\hline \multirow[t]{5}{*}{ Yanayacu } & All & 30 & 0.4 & 0.90 & no, $P=0.65$ \\
\hline & Falling & 0 & $x$ & $X$ & \\
\hline & High & 10 & 0.3 & 1.36 & \\
\hline & Low & 4 & 0.2 & 0.30 & \\
\hline & Rising & 16 & 0.5 & 0.80 & \\
\hline \multirow[t]{5}{*}{ Pucate } & All & 18 & 0.2 & 1.00 & no, $P=0.60^{1}$ \\
\hline & Falling & 2 & 0.2 & 1.40 & \\
\hline & High & 8 & 0.1 & 1.50 & \\
\hline & Low & 2 & 0.0 & 0.00 & \\
\hline & Rising & 6 & 0.4 & 0.45 & \\
\hline
\end{tabular}

* Single factor ANOVAs were used to compare means among seasons. When data were not normally distributed, the Kruskal-Wallis test was used to compare sample medians.

${ }^{1}$ indicates Sotalia not seen in this river during low water, and that statistical comparisons were made among the means from all other seasons.

Table 4. Seasonal depths of rivers lakes, and tucuxi depth thresholds.

\begin{tabular}{lccc}
\hline \hline \multicolumn{1}{c}{ LOCATION } & $\begin{array}{c}\text { MEAN MAXIMUM } \\
\text { DEPTH }(\mathrm{m})\end{array}$ & $\begin{array}{c}\text { MEAN } \\
\text { MINIMUM } \\
\text { DEPTH }(\mathrm{m})\end{array}$ & $\begin{array}{c}\text { SHALLOWEST } \\
\text { WATER (m) } \\
\text { WITH SOTALIA }\end{array}$ \\
\hline \hline Rivers & & & \\
\hline Marañón & 11.7 & 5.2 & 5.2 \\
Samiria (Section 1) & 7.4 & 3.0 & 3.0 \\
Samiria (Section 2) & 8.2 & 3.0 & 3.0 \\
Yanayaquillo & 10.8 & 4.7 & 5.7 \\
Atun Caño & 9.2 & 2.2 & 3.5 \\
Yanayacu & 15.4 & 4.5 & 4.5 \\
Pucate & 13.7 & 4.6 & 4.6 \\
\hline Lakes & & & \\
\hline San Pablo & 7.9 & 3.2 & 4.4 \\
Atun Cocha & 7.2 & 0.9 & 1.8 \\
Tipishca del Samiria & 7.4 & 3.8 & 3.8 \\
\hline \hline
\end{tabular}


Table 5. Tucuxi mean group size in rivers and lakes. An $\mathrm{x}$ indicates a location was not sampled frequently enough across seasons for statistical comparison.

\begin{tabular}{|c|c|c|c|c|}
\hline LOCATION & $\begin{array}{c}\text { SEASO } \\
\mathrm{N}\end{array}$ & $\begin{array}{c}\text { MEAN TUCUXI } \\
\text { GROUP SIZE } \\
( \pm S D) \\
\end{array}$ & $\begin{array}{c}\text { MAXIMUM } \\
\text { TUCUXI GROUP } \\
\text { SIZE } \\
\end{array}$ & $\begin{array}{c}\text { SIGNIFICANT SEASONAL } \\
\text { DIFFERENCES WITHIN A } \\
\text { LOCATION*? }\end{array}$ \\
\hline Yanayaquillo River & All & $1.2( \pm 0.41)$ & 2 & $\bar{x}$ \\
\hline Atun Caño & All & $2.0( \pm 0.00)$ & 2 & $x$ \\
\hline Yanayacu River & All & $1.6( \pm 0.66)$ & 3 & $x$ \\
\hline Pucate River & All & $2.0( \pm 0.87)$ & 3 & $\mathrm{x}$ \\
\hline \multirow[t]{5}{*}{ Marañón River } & All & $1.9( \pm 1.27)$ & 13 & no, $\mathrm{P}=0.09$ \\
\hline & Falling & $2.4( \pm 1.74)$ & 13 & \\
\hline & High & $1.9( \pm 1.15)$ & 5 & \\
\hline & Low & $1.9( \pm 1.34)$ & 6 & \\
\hline & Rising & $1.7( \pm 1.03)$ & 7 & \\
\hline \multirow[t]{5}{*}{$\begin{array}{l}\text { Samiria River } \\
\text { (section 1and 2) }\end{array}$} & All & $2.2( \pm 1.26)$ & 8 & $\begin{array}{c}\text { yes, } \mathrm{P}=0.0006 \\
\text { sig differences between } \\
\text { falling / low and } \\
\text { low / rising }\end{array}$ \\
\hline & Falling & $2.1( \pm 1.23)$ & 8 & \\
\hline & High & $2.1( \pm 1.06)$ & 5 & \\
\hline & Low & $2.5( \pm 1.45)$ & 8 & \\
\hline & Rising & $1.9( \pm 1.16)$ & 7 & \\
\hline \multirow[t]{5}{*}{ Lake San Pablo } & All & $2.4( \pm 1.44)$ & 7 & $\mathrm{no}^{1}, \mathrm{P}=0.056$ \\
\hline & Falling & $2.4( \pm 1.30)$ & 5 & \\
\hline & High & $2.9( \pm 1.41)$ & 7 & \\
\hline & Low & $0.0( \pm 0.00)$ & 0 & \\
\hline & Rising & $2.2( \pm 1.45)$ & 7 & \\
\hline \multirow[t]{5}{*}{ Lake Atun Cocha } & All & $1.9( \pm 3.05)$ & 6 & no, $\mathrm{P}=0.13$ \\
\hline & Falling & $2.0( \pm 0.60)$ & 3 & \\
\hline & High & $2.0( \pm 0.00)$ & 2 & \\
\hline & Low & $2.0( \pm 0.00)$ & 2 & \\
\hline & Rising & $1.8( \pm 1.03)$ & 6 & \\
\hline \multirow[t]{5}{*}{ Lake Tipishca del Samiria } & All & $2.4( \pm 1.75)$ & 13 & $\begin{array}{c}\text { yes, } \mathrm{P}=0.0001 \\
\text { sig diff between } \\
\text { falling/high and falling/ } \\
\text { rising }\end{array}$ \\
\hline & Falling & $2.9( \pm 1.92)$ & 11 & \\
\hline & High & $2.3( \pm 1.91)$ & 12 & \\
\hline & Low & $2.6( \pm 1.84)$ & 10 & \\
\hline & Rising & $2.2( \pm 1.58)$ & 13 & \\
\hline
\end{tabular}

* Single factor ANOVAs were used to compare means among seasons. When data were not normally distributed, the Kruskal-Wallis test was used to compare sample medians.

${ }^{1}$ indicates Sotalia not seen in this lake during low water, and that statistical comparisons were made among the means from all other seasons.

Table 6. Estimates of mean tucuxi abundance in Tipishca del Samiria; an x indicates that sampling did not occur (modified from Zúñiga, 1999).

\begin{tabular}{|c|c|c|c|c|c|c|c|c|c|}
\hline STUDY & METHOD & $\begin{array}{l}\text { OBSERVER } \\
\text { EYE HEIGHT }\end{array}$ & $\begin{array}{c}\# \\
\text { SURVEYS }\end{array}$ & $\begin{array}{l}\text { RISING } \\
\text { WATER }\end{array}$ & $\begin{array}{c}\text { HIGH } \\
\text { WATER }\end{array}$ & $\begin{array}{l}\text { FALLING } \\
\text { WATER }\end{array}$ & $\begin{array}{l}\text { LOW } \\
\text { WATER }\end{array}$ & $\begin{array}{c}\text { MEAN } \\
\text { ABUNDANCE } \\
\text { AND SD }\end{array}$ & $\mathrm{CV}$ \\
\hline $\begin{array}{c}\text { Leatherwood } \\
\text { (1996) }\end{array}$ & $\begin{array}{c}\text { line transect, } \\
\text { zigzag }\end{array}$ & $7 \mathrm{~m}$ & 13 & $x$ & 19 & 26 & $x$ & 20 & 0.29 \\
\hline $\begin{array}{c}\text { Leatherwood } \\
\text { (1996) }\end{array}$ & $\begin{array}{l}\text { direct count, } \\
\text { loop }\end{array}$ & $1-2 \mathrm{~m}$ & 3 & $x$ & 16 & 23 & $x$ & 18 & 0.24 \\
\hline $\begin{array}{l}\text { Henningsen } \\
\text { (1998) }\end{array}$ & $\begin{array}{l}\text { direct count, } \\
\text { loop }\end{array}$ & unspecified & 2 & $x$ & 30 & $x$ & 30 & 30 & 0 \\
\hline $\begin{array}{l}\text { Zúñiga } \\
\text { (1999) }\end{array}$ & $\begin{array}{l}\text { direct count, } \\
\text { modified } \\
\text { zigzag }\end{array}$ & $1-2 \mathrm{~m}$ & 78 & 22 & 22 & 17 & 11 & 20 & 0.71 \\
\hline $\begin{array}{l}\text { McGuire } \\
\text { (2002) }\end{array}$ & $\begin{array}{l}\text { direct count, } \\
\text { zigzag }\end{array}$ & $3.5-7 \mathrm{~m}$ & 29 & 49 & 25 & 22 & 20 & 27 & 0.63 \\
\hline
\end{tabular}


Table 7. Comparison of direct counts of tucuxi obtained with different routes and vessels on the same day or consecutive days, Tipishca del Samiria. For detailed methods, see Zúñiga (1998) and McGuire (2002).

\begin{tabular}{cccccc}
\hline \hline DATE & SEASON & $\begin{array}{c}\text { OBSERVER } \\
\text { EYE HEIGHT } \\
(\mathrm{m})\end{array}$ & ROUTE & \# SOTALIA & $\begin{array}{c}\text { RATIO OF } \\
\text { DIRECT COUNTS }\end{array}$ \\
\hline \hline 17 July 1998 & falling & 7 & zigzag & 18 & \\
17 July 1998 & falling & 1 & modified zigzag & 6 & $3.0: 1.0$ \\
& & & & & \\
21 March 1998 & high & 7 & zigzag & 54 & $1.2: 1.0$ \\
21 March 1998 & high & 1 & modified zigzag & 46 & \\
& & & & & \\
23 Jan 1998 & rising & 7 & zigzag & 54 & $1.3: 1.0$ \\
24 Jan 1998 & rising & 1 & modified zigzag & 42 & $1.3: 1.0$ \\
\hline \hline
\end{tabular}

\section{Discussion}

Confluences were areas of greatest tucuxi densities, which is not surprising given that confluences are known to provide year-round availability of deep water and high densities of fish (Lowe-McConnell, 1975; 1979). Tucuxi encounter rates were higher in lakes than rivers, and in wider rivers rather than narrow channels, which is consistent with diet studies (da Silva, 1983) indicating that tucuxi primarily consume schooling fish found in open waters. It would be interesting to know if a longitudinal density gradient for tucuxis exists along the Amazon River, with densities increasing as the river widens toward the delta. Encounter rates from tucuxis in the study were within the range of encounter rates reported elsewhere in the Amazon (Borobia et al., 1991), although it is difficult to compare densities obtained with the variety of methods used in different study areas. Absolute water depth, rather than relative seasonal changes in depth, appeared to have been most strongly associated with tucuxi distribution. Rather than exhibiting a predicted gradual change in distribution which closely tracked water levels, tucuxis remained in lakes and smaller rivers until a minimum depth threshold was reached, at which point they moved to confluence areas. Distinct seasonal changes in group size might have suggested the onset of a mating and/or calving season, but insubstantial $(<1)$ changes in mean group size and observations of aseasonal calving and mating behavior indicate that reproduction occurs yearround in the Peruvian study area.

Photo-identification was unsuccessful as tucuxis were difficult to identify because they avoided boats, did not remain long in any one area, and surfaced quickly and unpredictably. Trujillo (1994), Henningsen (1998), and Zúñiga (1999) had some success with photo-ID of tucuxi, although they did not find the technique robust enough to study social structure or estimate population size. Future photo-identification results may improve with focal follows and digital video camera with screen capture.

Differences in survey methods, such as observer eye height, transect type, number of observers, vessel speed, use of correction factors, and frequency of survey all affected population estimates. Considering the high degree of intra-seasonal and daily variability (differences within a location as great as 51 and 17 dolphins, respectively) of tucuxi counts made by the same researcher using the same method in the same locations, it should be emphasized that future population assessment should sample frequently within seasons as well as between, use standardized methodology, and be aware that 'rapid assessment transect' type surveys may yield misleading results.

Local people in the Reserve did not seem to have the same myths and general apprehension about tucuxis as for the other sympatric dolphin, Inia. There was no evidence that tucuxi were poisoned by fishermen, unlike Inia (Reeves et al., 1999). It is remarkable that only one dead tucuxi was encountered during the study, while 12 dead Inia were encountered during this time, and live tucuxi and Inia were encountered in approximately equal numbers (McGuire, 2002). The apparent lower rate of anthropogenic mortality of tucuxis compared to botos may be due to differences in local attitudes towards the two species. Potential threats to tucuxi in this region were entanglement in fishing gear, over fishing of prey fish by humans, mercury in migratory fish from gold mining elsewhere, oil spills, ship strikes, water pollution, and disturbance from boats. Tucuxi teeth were found in local markets; although cause of death could not be determined, vendors reported the dolphins had been killed incidentally in fishing nets. As of 2000, tucuxi populations in the Pacaya-Samiria Reserve appeared to be relatively healthy, and studies indicate that population estimates in the Samiria River system were stable over the period 1991-2000 (Leatherwood, 1996; Henningsen, 1998; Zúñiga, 1999; McGuire, 2002). 


\section{Acknowledgements}

The following people and institutions are thanked: The administration and field workers of the Pacaya-Samiria National Reserve, the crews of the Delfin and Miron Lento, Marc Bourdon, the DeMatteos, Earthwatch Institute, Francisco Estremadoyro, Familias Aliaga, Pinedo and Tenazoa, INRENA, Dave Jepsen, Thomas Henningsen, the Kramarae/Kramer family, LGL Alaska Research, Steve Leatherwood, the McGuires, Víctor Morales, Oceanic Society Expeditions, Gustavo PereyraPanduro, Dulcie Powell, Pronaturaleza, Randy Reeves, the Texas Institute of Oceanography, Gerónimo Vega Quevare, the Virtual Explorers, Kirk Winemiller, Bernd Würsig, Elizabeth Zúñiga, and the volunteers of Earthwatch, Elderhostel, and the Oceanic Society. Thanks to Enzo Aliaga-Rossel, Barb Lagerquist, Lucy Moore, and Paulo Flores for their helpful reviews. This research was conducted under permits \#53-97, \#27-99, \#02-S/C 2000-INRENA-DGANPFS-DANP.

\section{References}

Best, R.C. And Da Silva, V.M.F. (1989) Biology, status and conservation of Inia geoffrensis in the Amazon and Orinoco basin. Pages 23-34 in Perrin, W. F, Brownell, Jr., R. L., KaiYA, Z. AND JiankANG, L. (Eds) Biology and Conservation of the River Dolphins. International Union for Conservation of Nature and Natural Resources (IUCN), Species Survival Commission, Occasional Paper 3. IUCN, Gland, Switzerland.

Borobia, M., SicILANO, S., LOdI, L. AND HoEK, W. (1991) Distribution of the South American dolphin Sotalia fluviatilis. Canadian Journal of Zoology 69: 1025-1039. http://dx.doi.org/10.1139/z91-148

DA SILVA, V.M.F. (1983) Ecologia alimentar dos golfinhos da Amazonia. M.Sc. thesis. University of Amazonas. Manaus, Brazil. 118 pp.

DA SILVA, V.M.F. (1994) Aspects of the biology of the Amazonian dolphins genus Inia and Sotalia fluviatilis. Ph.D. Thesis. St. John's College, Cambridge University. Cambridge, England. 327 pp.

DA Silva, V.M.F., And Best, R.C. (1996) Sotalia fluviatilis. Mammalian Species 527:1-7. http:/ / dx.doi.org/10.2307/3504117

GALINDO, M.A. (1998) Estimación de abundancia y distribución de los delfines de agua dulce Inia geoffrensis y Sotalia fluviatilis en el Río Caquetá (la Pedrera-Depto. Amazonas). B.Sc. Thesis. Universidad del Valle. Cali, Colombia. 93 pp.

Henningsen, T. (1998). Zur Verbreitung, Habitatwahl und Verhaltensökologie der Delphine Inia geoffrensis und Sotalia fluviatilis im Oberlauf des Amazonas. Ph.D. Thesis. Zentrum für Marine Tropenökologie. Bremen, Germany. 139 pp.

Herman, L.H., von Fersen, L. and Solangi, M. (1996) The bufeo (Inia geoffrensis) in the Rio Lagarto Cocha of the Ecuadorian Amazon. Marine Mammal Science 12(1): 118-125. http://dx.doi.org/10.1111/j.1748-7692.1996.tb00309.x

LAYNE, J.N. (1958) Observations on freshwater dolphins in the upper Amazon. Journal of Mammalogy 39:1-22. http:/ / dx.doi.org/ $10.2307 / 1376605$

LEATHERWOOD, J.S. (1996) Distributional ecology and conservation status of river dolphins (Inia geoffrensis and Sotalia fluviatilis) in portions of the Peruvian Amazon. Ph.D. Thesis. Texas A\&M
University. College Station, Texas, USA. 233 pp.

LeATHERWOOOD, S., REEVES, R.R., WÜRSIG, B. AND SHEARN, D. (2000) Habitat preferences of river dolphins in the Peruvian Amazon. Pages 131-144 in ReEves, R. R, SMITH, B. D., AND KasuYA, T. (Eds) Biology and conservation of freshwater cetaceans in Asia. International Union for Conservation of Nature and Natural Resources (IUCN), Species Survival Commission, Occasional Paper 23. IUCN, Gland, Switzerland.

Lowe-McConnell, R.H. (1975) Fish communities in tropical freshwaters. Longman, London, England.

LOWE-McConNELL, R.H. (1979) Ecological aspects of seasonality in fishes of tropical waters. Symposium Zoological Society London 44: 219-241.

Magnusson, W.E., Best, R.C. AND dA SILVA, V.M.F. (1980) Number and behavior of Amazon dolphins, Inia geoffrensis and Sotalia fluviatilis in the Rio Solimoes, Brazil. Aquatic Mammals 8: 27-32.

Martin, A.R., DA SILVA, V.M.F. AND SALmON, D.L. (2004) Riverine habitat preferences of botos (Inia geoffrensis) and tucuxis (Sotalia fluviatilis) in the Central Amazon. Marine Mammal Science 20(2): 189-200. http://dx.doi.org/10.1111/j.1748-7692.2004.tb01150.x

McGuire, T.L. (2002) Distribution and abundance of river dolphins in the Peruvian Amazon. Ph.D. Thesis. Texas A\&M University. College Station, Texas, USA. 254 pp.

McGuire, T.L., AND Aliaga-Rossel, R. (2007) Seasonality of reproduction in Amazon River dolphins (Inia geoffrensis) in three major river basins of South America. Biotropica 39(1): 139-135. http:// dx.doi.org/10.1111/j.1744-7429.2006.00221.x

McGuire,T.L. AND HENNInGSEN, T. (2007) Movement patterns and site fidelity of river dolphins (Inia geoffrensis and Sotalia fluviatilis) in the Peruvian Amazon as determined by photo-identification. Aquatic Mammals 33: 359-367. http://dx.doi.org/10.1578/ AM.33.3.2007.359

Reeves, R.R., McGuire, T.L. AND ZúÑIgA, E.L. (1999) Ecology and conservation of river dolphins in the Peruvian Amazon. International Marine Biological Research Institute Reports 9: 21-32.

TrujlLlo, F. (1994) The use of photoidentification to study the Amazon river dolphin, Inia geoffrensis, in the Colombian Amazon. Marine Mammal Science 10(3): 348-353.

Trujillo, F. (1992) Estimacion poblacional de las especies dulceacuicolas de delfines Inia geoffrensis y Sotalia fluviatilis en el sistema lacustre de Tarapoto y El Correo, Amazonia Colombiana. Informe Especial Fundación UJTL-CIC, Colombia. 50 pp.

Vidal, O., Barlow, J., Hurtado, L. A., Torre, J., Cendon, P. and OJEDA, Z. (1997) Distribution and abundance of the Amazon River dolphin (Inia geoffrensis) and the tucuxi (Sotalia fluviatilis) in the upper Amazon River. Marine Mammal Science 13(3): 42745. http://dx.doi.org/10.1111/j.1748-7692.1997.tb00650.x

ZúNiga, E.L. (1999) Seasonal distribution of freshwater dolphins in Tipishca del Samiria, Peru. M.Sc. Thesis. Texas A\&M University, College Station. Texas, USA. 126 pp.

Received on 31 July 2008. Accepted on 4 September 2010. Managed by Marcos Santos. 